\title{
Recent advances in bismuth-containing photocatalysts with heterojunctions
}

\author{
Lang Chen, Jie He, Ying Liu, Peng Chen, Chak-Tong Au, Shuang-Feng Yin* \\ State Key Laboratory of Chemo/Biosensing and Chemometrics, College of Chemistry and Chemical Engineering, Hunan University, Changsha 410082, \\ Hunan, China
}

\section{A R T I C L E I N F O}

Article history:

Received 19 January 2016

Accepted 20 February 2016

Published 5 June 2016

\section{Keywords:}

Photocatalysis

Bismuth

Heterojunction

Visible light

\begin{abstract}
A B S T R A C T
Photocatalysis has received much attention owing to current energy and environmental crises. The use of an appropriate photocatalyst is important to a photocatalytic process. The development of photocatalysts that absorb light over a wide range of wavelengths and efficiently separate charge carriers remains a challenge and hot research topic. With strong visible-light-absorption ability, bismuth-containing photocatalysts are of great interest to scientists. However, measures have to be taken to enhance the light absorption efficiency and to lessen the problem of the recombination of charge carriers. Known approaches are the formation of heterojunctions through (1) loading of a noble metal, (2) semiconductor combination, (3) metal and nonmetal doping, (4) carbon-based material modification, and (5) Bi metal loading. The present review summarizes recent advances in this respect. Finally, the future development and potential applications of bismuth-containing photocatalysts with heterojunctions are briefly discussed.
\end{abstract}

(C) 2016, Dalian Institute of Chemical Physics, Chinese Academy of Sciences. Published by Elsevier B.V. All rights reserved.

\section{Introduction}

Photocatalysis is regarded as the most promising technique for solving the problems of energy shortages and environmental pollution, which threaten the future development of human society. Photocatalytic technology has bright prospects in areas such as the generation of clean hydrogen by water splitting, $\mathrm{CO}_{2}$ reduction into useful organics, and organic synthesis under mild conditions. Furthermore, the photocatalytic decomposition of organic and/or inorganic pollutants into $\mathrm{CO}_{2}, \mathrm{H}_{2} \mathrm{O}$ and nontoxic products without secondary pollutants has been considered a potential method of environmental remediation [1-6].

Since Fujishima and co-workers reported $\mathrm{TiO}_{2}$ as a photocatalyst for $\mathrm{H}_{2}$ and $\mathrm{O}_{2}$ generation from water splitting [7], much attention has been paid to $\mathrm{TiO}_{2}$ and $\mathrm{TiO}_{2}$-based photocatalysts $[8,9]$. However, with a wide band gap of $3.2 \mathrm{eV}, \mathrm{TiO}_{2}$ can only be excited under ultraviolet irradiation and it uses less than $4 \%$ of solar energy. Much effort has thus been made to improve the visible light absorption ability of $\mathrm{TiO}_{2}$; such efforts include noble metal loading, element doping and combining $\mathrm{TiO}_{2}$ with semiconductors having narrow band gaps. Meanwhile, achievements have been made in the development of novel photocatalysts driven by visible light. Among novel photocatalysts, bismuth-containing photocatalysts have received tremendous attention, and their advancement has been summarized systematically by $\mathrm{Yu}$ and co-workers [10]. They presented the types of bismuth-containing photocatalysts and discussed the effects of the preparation method, structure, morphology, and composition on photocatalytic properties. Despite

\footnotetext{
* Corresponding author. Tel/Fax: +86-731-88821171. E-mail: sf_yin@hnu.edu.cn

This work was supported by the National Natural Science Foundation of China (21401054, 21476065), the China Postdoctoral Science Foundation (2014M562098), and the Fundamental Research Funds for the Central Universities.

DOI: 10.1016/S1872-2067(15)61061-0 | http://www.sciencedirect.com/science/journal/18722067 | Chin. J. Catal., Vol. 37, No. 6, June 2016
} 
much effort, a practically viable photocatalyst that is cheap and possesses sufficient efficiency and stability is yet to be found. Indeed, it is difficult to simultaneously fulfill the different metrics with a single material.

The recombination of photogenerated electrons and holes goes against the photocatalytic process. Since Li and coworkers first reported the high separation efficiency of charge carriers over heterojunction photocatalysts [11,12], there has been much similar research [13-15]. It is generally regarded that the drawbacks of single-component photocatalysts can be eliminated through the synthesis of a heterogeneous photocatalyst of integrated functional components that combines the advantages of the individual components. In this article, we present a wide range of heterojunctions fabricated to enhance the performance of bismuth-containing photocatalysts. The heterojunctions are noble metal/Bi-containing composite, semiconductor/Bi-containing composite, heterojunctions between two Bi-containing photocatalysts, carbon-based material/Bicontaining composite, and $\mathrm{Bi}$ metal/Bi-containing semiconductor. Finally, we briefly discuss the future development and potential applications of this class of photocatalysts.

\section{Bismuth-containing photocatalysts loaded with a noble metal (Schottky junction)}

With excellent conductivity and strong electron trapping ability, noble metals are used in photocatalysis for the separation and transfer of light-excited charge carriers. Under visible light, the transfer of charge carriers between the noble metal and support (semiconductor) can follow two pathways. In one case, the support of a wide band gap cannot be excited under visible-light irradiation but there is a transfer of electrons from the surface plasmon of the noble metal. In the other case, which is normally observed, there is a transfer of excited electrons from the semiconductor to noble metal. Furthermore, the noble metal of nanostructures can induce surface plasmon resonance (SPR), which can broaden the light absorption range of a composite photocatalyst [16]. In recent years, noble metals have been widely used as cocatalysts to enhance photocatalytic activity, especially in the areas of water splitting and the selective oxidation of organics.

As reported by Manna et al. [17], because of lattice similarity between $\mathrm{Au}$ and $\mathrm{Bi}_{2} \mathrm{~S}_{3}$, a junction forms between the (101) plane of $\mathrm{Au}$ and (221) plane of $\mathrm{Bi}_{2} \mathrm{~S}_{3}$. With the formation of heterojunctions, the light absorption is red-shifted and the SPR peak of Au broadens from ca. 520 to $560 \mathrm{~nm}$ (Fig. 1(a) and (b)). When photocatalytic reduction of methylene blue (MB) under visible-light irradiation (500-nm monochromatic light) is used as a probe reaction, the transfer of photogenerated electrons observed over the $\mathrm{Au}-\mathrm{Bi}_{2} \mathrm{~S}_{3}$ heterojunctions is much faster than that over $\mathrm{Au}$ or $\mathrm{Bi}_{2} \mathrm{~S}_{3}$. The $\mathrm{Au}-\mathrm{Bi}_{2} \mathrm{~S}_{3}$ photocatalyst is typically nanostructured, and the improvement in photocatalytic activity can be attributed to the enhanced separation of charge carriers and the broadened light absorption range as a result of the noble metal plasmon (Fig. 1(c) and (d)). Owing to the fast electron transfer from the semiconductor to noble metal, Pt-coupled $\mathrm{Bi}_{2} \mathrm{WO}_{6}$ composite shows highly selective and efficient conversion of aromatic alcohols to their corresponding
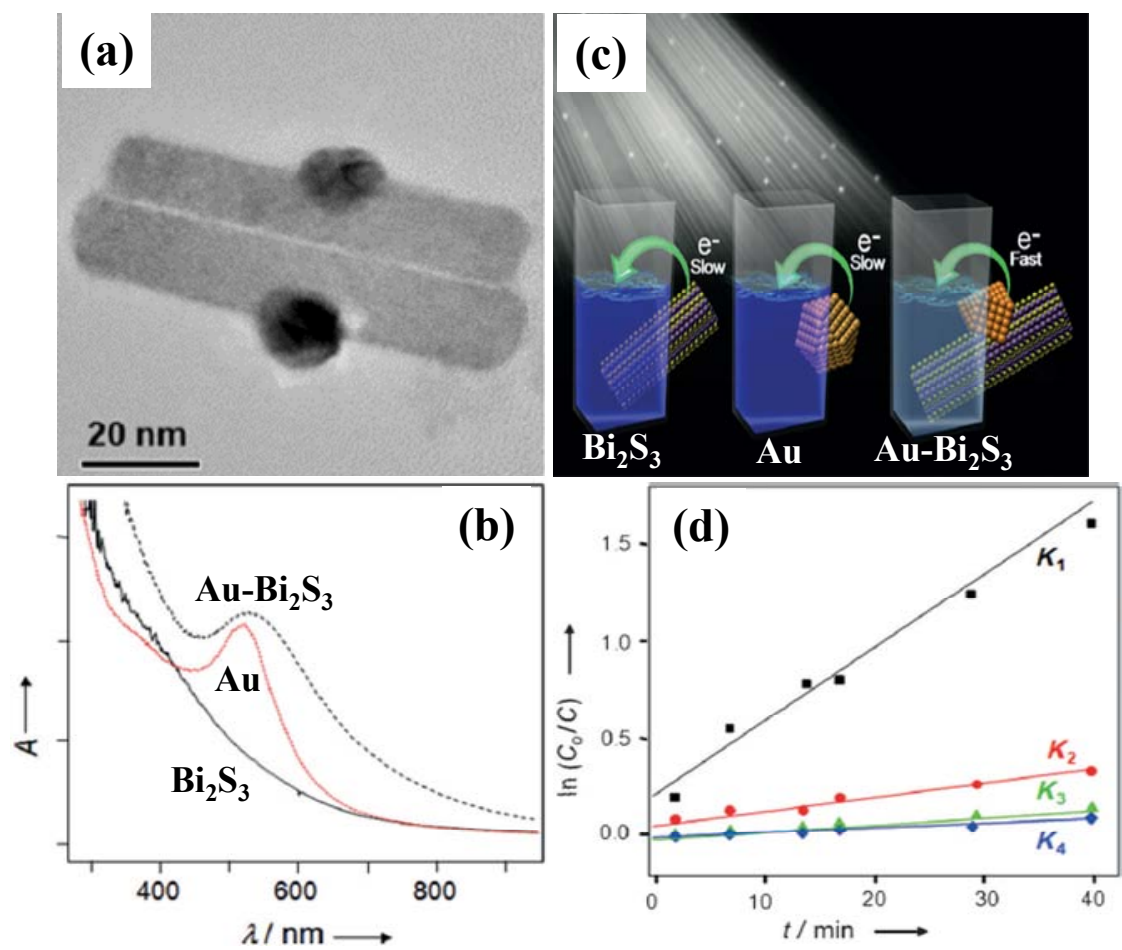

Fig. 1. (a) Transmission electron microscopy image of the $\mathrm{Au}-\mathrm{Bi}_{2} \mathrm{~S}_{3}$ heterostructure. (b) Light absorption spectra of $\mathrm{Bi}_{2} \mathrm{~S}_{3}$ rods, $\mathrm{Au}$ nanoparticles and $\mathrm{Au}-\mathrm{Bi}_{2} \mathrm{~S}_{3}$ heterostructures. (c) Schematic of the favorable photoreduction of MB. (d) Rate of dye degradation with irradiation progress controlled under different conditions. The samples were irradiated using a Xe lamp with a wavelength of $500 \mathrm{~nm} . k_{1}\left(0.037 \mathrm{~min}^{-1}\right), k_{2}\left(0.007 \mathrm{~min}^{-1}\right), k_{3}(0.004$ $\left.\mathrm{min}^{-1}\right)$, and $k_{4}\left(0.002 \mathrm{~min}^{-1}\right)$ denote the dye-degradation rate constants when $\mathrm{Au}-\mathrm{Bi}_{2} \mathrm{~S}_{3}$, a mixture of $\mathrm{Au}$ and $\mathrm{Bi}_{2} \mathrm{~S}_{3}, \mathrm{Bi}_{2} \mathrm{~S}_{3}$, and $\mathrm{Au}$ were used as catalyst, respectively [17]. 
aldehydes under simulated sunlight and ambient conditions. It has been pointed out that, rather than there being a mechanism of direct oxidation involving $\cdot \mathrm{O}_{2}{ }^{-}$in the conduction band, the valance band holes are the main active sites for the two-step oxidation of alcohols, and the transfer of hot electrons to Pt can prevent the recombination of charge carriers efficiently [18].

Besides $\mathrm{Au}$, other noble metals such as $\mathrm{Pt}, \mathrm{Pd}, \mathrm{Rh}$ and $\mathrm{Ag}$ have been used to modify Bi-containing semiconductors to fabricate plasmonic photocatalysts [19-23]. Among them, Ag is relatively cheap and has hence received more attention. For example, Luo et al. [19] prepared $\mathrm{Ag} / \mathrm{Bi}_{3} \mathrm{TaO}_{7}$ composite that had enhanced activity towards the degradation of tetracycline under visible light. They also ascribed the enhanced activity to the SPR effect of Ag and the enhanced separation of charge carriers at heterojunctions. Photoreduction is the most commonly used method for the fabrication of Ag-modified photocatalysts. However, the method is complicated by the two separated processes. Taking $\mathrm{Ag} / \mathrm{BiVO}_{4}$ as an example, steps for the synthesis of $\mathrm{Ag} / \mathrm{BiVO}_{4}$ composites involve a sol-gel procedure followed by a photoreduction process, and the as-prepared samples are not porous [24,25]. Our group [26] fabricated hollow and porous $\mathrm{Ag} / \mathrm{BiVO}_{4}$ composites employing a one-step hydrothermal method (Fig. 2(a) and (b)). Compared with those prepared by photoreduction, the composites prepared employing the one-step method show higher activity towards dye degradation. Besides the SPR effect of Ag and separation enhancement of charge carriers at the heterojunctions, it is deduced that the hollow and porous structure plays an important role in activity improvement as a result of enhanced light absorption efficiency (Fig. 2(c) and (d)).

Through the fabrication of Schottky junctions, the light ab- sorption ability and the separation of charge carriers can be enhanced. However, owing to low interaction between the noble metal and semiconductor and the agglomeration of noble metals in the photocatalytic process, the reusability of plasmonic photocatalysts is unsatisfactory. In view of this and the high cost of noble metals, there is a need to fabricate heterojunctions of other kinds. In other words, the generation of heterojunctions between two semiconductors and/or between a semiconductor and another kind of material is of great importance.

\section{Heterojunctions between two semiconductors}

$\mathrm{Li}$ and co-workers $[11,12]$ reported that the formation of surface junctions between anatase- and rutile-phase $\mathrm{TiO}_{2}$ as well as the formation of surface junctions between $\mathrm{MoS}_{2}$ and CdS can greatly enhance the photocatalytic activity by accelerating the separation of photogenerated electrons and holes. Much attention has since been paid to constructing composite photocatalysts that are rich in heterojunctions.

\subsection{Bismuth-containing photocatalysts with other semiconductors}

Owing to their strong visible-light absorption ability and relatively high oxidation ability, bismuth-containing photocatalysts have been widely combined with other semiconductors (such as $\mathrm{TiO}_{2}$ [27-33], $\mathrm{ZnO}$ [34], $\mathrm{Ag}_{3} \mathrm{PO}_{4}$ [35-37], $\mathrm{CuS}$ [38], $\mathrm{WO}_{3}$ [39], $\gamma-\mathrm{Fe}_{2} \mathrm{O}_{3}$ [40,41], $\mathrm{CeO}_{2}$ [42], $\mathrm{CaFe}_{2} \mathrm{O}_{4}$ [43] and $\mathrm{Cu}_{2} \mathrm{O}$ [44-47]) to form heterojunctions. In these composites, the bismuth-containing photocatalysts not only play an important
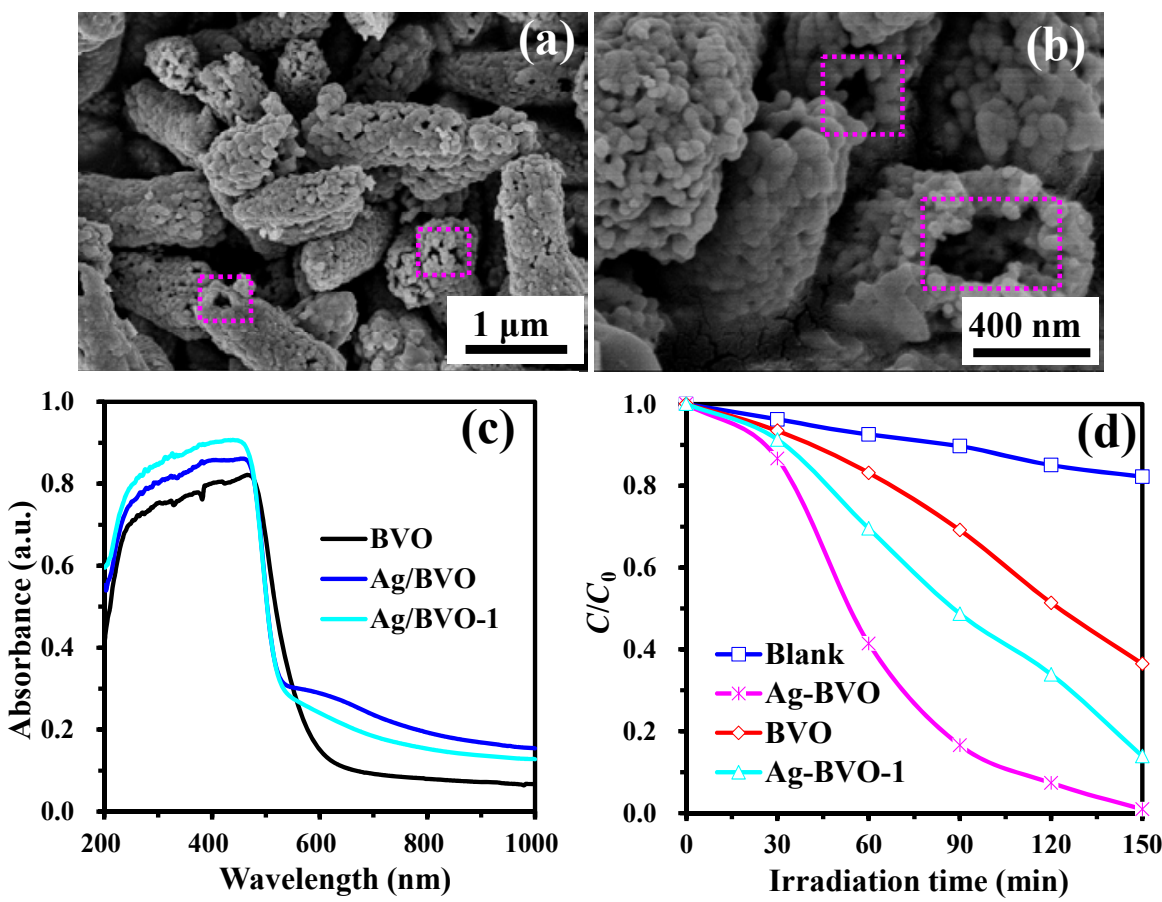

Fig. 2. (a) and (b) Scanning electron microscopy images of hollow and porous $\mathrm{Ag} / \mathrm{BiVO}_{4}$ prepared employing the one-step method. (c) Light absorption of samples. (d) Photocatalytic activity for MB degradation under visible-light irradiation (300 W Xe lamp with a 420-nm cutoff filter). BVO, $\mathrm{Ag} / \mathrm{BVO}$ and $\mathrm{Ag} / \mathrm{BVO}-1$ refer to $\mathrm{BiVO}_{4}, \mathrm{Ag} / \mathrm{BiVO}_{4}$ prepared employing the one-step method and $\mathrm{Ag} / \mathrm{BiVO}_{4}$ prepared employing the traditional photoreduction method, respectively [26]. 
role in preventing the recombination of charge carriers but also act as visible-light sensitizers. Taking $\mathrm{TiO}_{2}$ as an example, Naik and co-workers [28] reported that the $\mathrm{Bi}_{2} \mathrm{O}_{3}$ sensitization of $\mathrm{TiO}_{2-\mathrm{x}} \mathrm{N}_{x}$ led to an excellent light harvesting capability and good charge transfer, resulting in enhanced visible-light activity for the selective hydroxylation of phenol to hydroquinone. Enhanced performance was reported by Jiang et al. [30] $\left(\mathrm{Bi}_{2} \mathrm{O}_{3}-\mathrm{TiO}_{2}\right)$, Lu et al. [31] $\left(\mathrm{Bi}_{2} \mathrm{~S}_{3}-\mathrm{TiO}_{2}\right)$ and $\mathrm{Li}$ et al. [29] $\left(\mathrm{Bi}_{2} \mathrm{MoO}_{6}-\mathrm{TiO}_{2}\right)$ when a Bi-containing semiconductor was loaded on $\mathrm{TiO}_{2}$. Besides the formation of heterojunctions between $\mathrm{Bi}_{2} \mathrm{O}_{3}$ and $\mathrm{TiO}_{2}$, bidirectional doping can also enhance photocatalytic activity as reported by Li et al. [27]. They found that the light absorption edge of $\mathrm{TiO}_{2}$-NTs could be extended to $495 \mathrm{~nm}$ by modification with Bi species. Additionally, the valance band of $\mathrm{Bi}_{2} \mathrm{O}_{3}$ was lowered from 2.02 to $2.28 \mathrm{eV}$ through interaction with the Ti species. Consequently, the combination of $\beta-\mathrm{Bi}_{2} \mathrm{O}_{3}$ with stake-structured $\mathrm{TiO}_{2}$-NTs resulted in much higher activity towards carbamazepine degradation under visible-light irradiation.

The photocatalytic activity of bismuth-containing photocatalysts can also be enhanced by modification with other semiconductors. $\mathrm{Ag}_{3} \mathrm{PO}_{4}$, which has strong oxidation power, can achieve quantum efficiency up to $90 \%$ for $\mathrm{O}_{2}$ generation through water splitting under visible-light irradiation. As reported by $\mathrm{Xu}$ et al. [37], the monodispersion of $\mathrm{Ag}_{3} \mathrm{PO}_{4}$ on the surface of spherical $\mathrm{Bi}_{2} \mathrm{MoO}_{6}$ resulted in enhanced photocatalytic activity in the decolorization of $\mathrm{MB}$ and Rhodamine $\mathrm{B}$ (Rh-B). They ascribed the phenomena to the extension of the light absorption region and the efficient separation of charge carriers at the $\mathrm{Ag}_{3} \mathrm{PO}_{4} / \mathrm{Bi}_{2} \mathrm{MoO}_{6}$ interfaces. Recently, Zhang and co-workers [36] found that if there is a partial reduction of $\mathrm{Ag}^{+}$ to $\mathrm{Ag}^{0}$ at the surface of $\mathrm{Ag}_{3} \mathrm{PO}_{4} / \mathrm{Bi}_{2} \mathrm{MoO}_{6}$, then there is the formation of $\mathrm{Ag} / \mathrm{Ag}_{3} \mathrm{PO}_{4} / \mathrm{Bi}_{2} \mathrm{MoO}_{6}$ having even higher activity than $\mathrm{Ag}_{3} \mathrm{PO}_{4} / \mathrm{Bi}_{2} \mathrm{MoO}_{6}$ owing to the strong electron trapping property of Ag. Similar enhancement was also observed over the $\mathrm{Ag}_{3} \mathrm{PO}_{4} / \mathrm{BiOBr}$ composite [36].

Recently, $\mathrm{Li}$ and co-workers pointed out that the selective deposition of co-catalysts on certain facets of polyhedron semiconductors could optimize photocatalytic activities [48]. They found that the selective loading of reduction and oxidation co-catalysts on (010) and (110) facets, respectively, produced composites that have much higher activity in both photocatalytic and photoelectrocatalytic water oxidation. Therefore, the combination of morphology engineering and heterojunction fabrication could be a practical approach for designing composite photocatalysts of high activity. Gong and co-workers [35] reported the selective deposition of $\mathrm{Ag}_{3} \mathrm{PO}_{4}$ on the (040) facets of $\mathrm{BiVO}_{4}$ and the as-resulted composite showed enhanced activity for dye degradation under visible light (Fig. 3). Most recently, Li et al. [49] fabricated a Z-scheme photocatalyst by decorating the (040) facet of $\mathrm{BiVO}_{4}$ with $\mathrm{Ag} @ \mathrm{AgCl}$, which showed much higher activity than $\mathrm{Ag} / \mathrm{BiVO}_{4}$ and $\mathrm{BiVO}_{4}$.

Photocatalytic processes are commonly divided into three steps: (1) light harvesting and generation of charge carriers; (2) charge carrier separation and transfer to the surface of catalysts; and (3) redox reaction on the surface of catalysts. To some extent, the efficient utilization of surface electrons and holes is also critical for photocatalytic efficiency. In our research [47], we fabricated the $\mathrm{Cu}_{2} \mathrm{O} / \mathrm{BiVO}_{4}$ composite and used it as photocatalyst for the simultaneous oxidation of organic
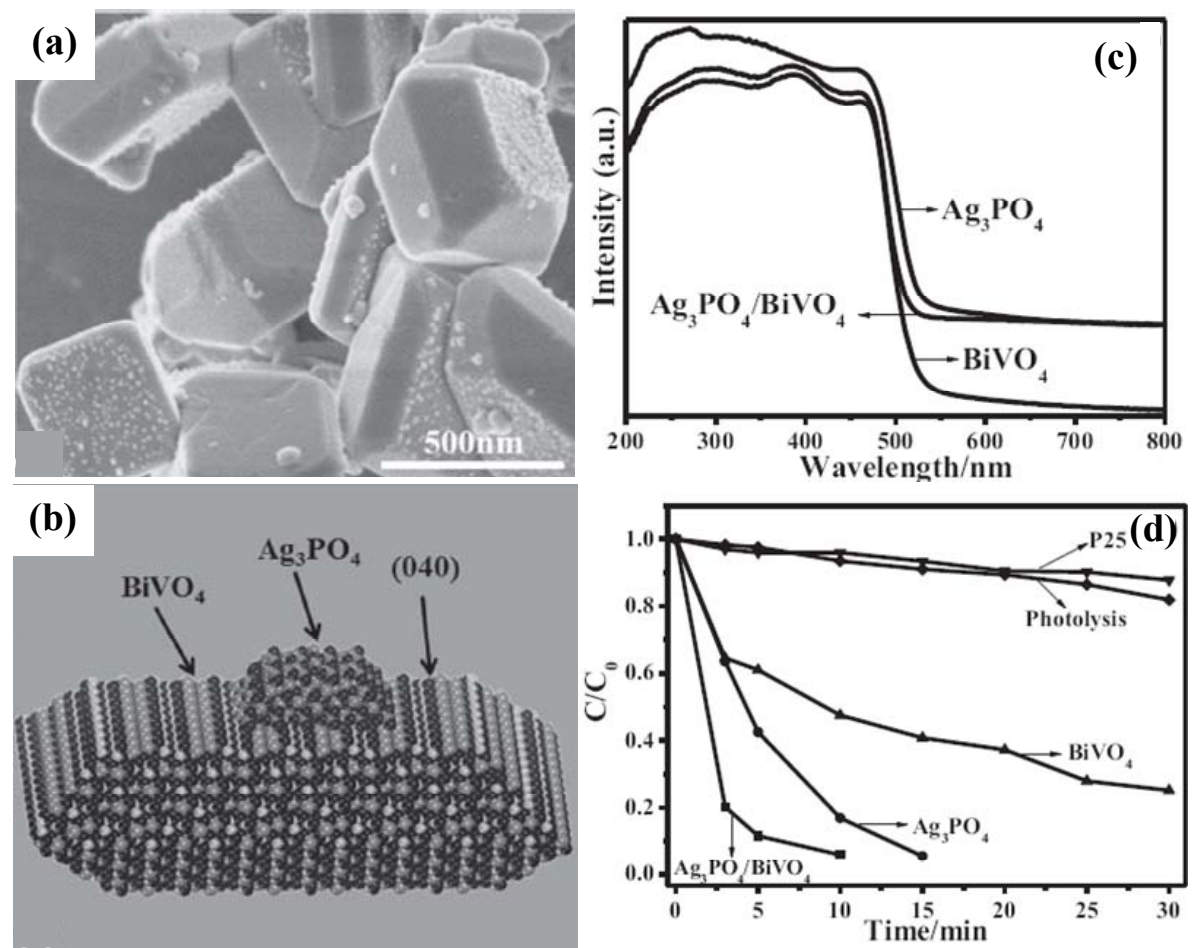

Fig. 3. (a) Scanning electron microscopy image of $\mathrm{Ag}_{3} \mathrm{PO}_{4} / \mathrm{BiVO}_{4}$ composite. (b) Illustration of the $\mathrm{Ag}_{3} \mathrm{PO}_{4} / \mathrm{BiVO}_{4}$ photocatalyst in the atom ball model, in which $\mathrm{Ag}_{3} \mathrm{PO}_{4}$ nanoparticles (small domain) are distributed on $\mathrm{BiVO}_{4}(040)$ facets. Black, gray, white, light gray and dark gray spheres represent $\mathrm{O}$, $\mathrm{Bi}, \mathrm{V}, \mathrm{P}$ and Ag, respectively. (c) UV-vis diffuse reflectance spectra of the as-synthesized samples. (d) Photocatalytic degradation of MB over as-prepared photocatalysts under visible-light irradiation [35]. 

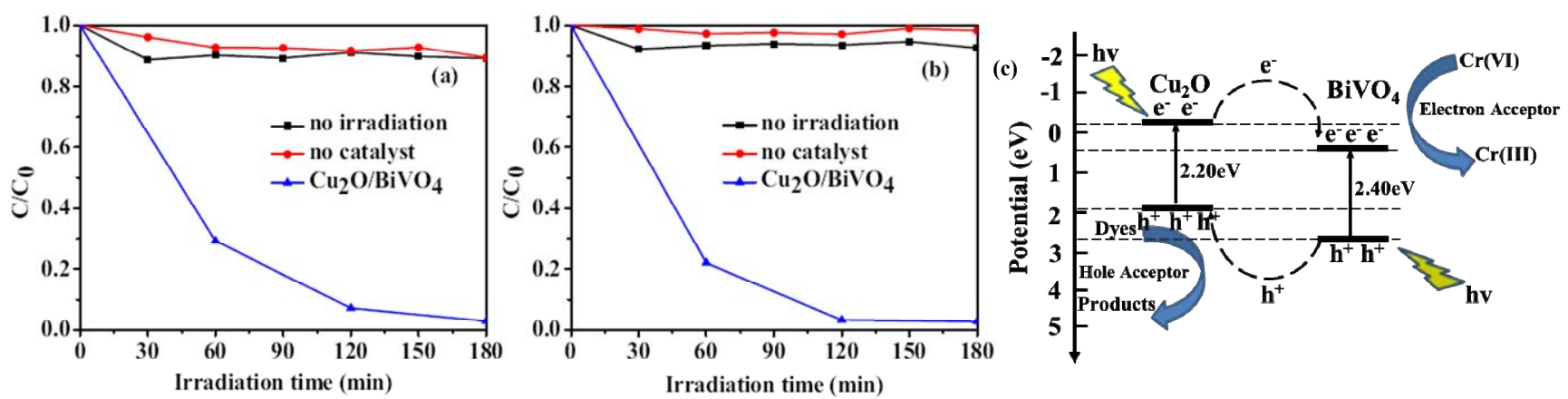

Fig. 4. (a) and (b) Simultaneous photocatalytic oxidation of $\mathrm{RhB}\left(1 \times 10^{-5} \mathrm{~mol} / \mathrm{L}\right)$ and reduction of $\mathrm{Cr}(\mathrm{VI})\left(8 \times 10^{-5} \mathrm{~mol} / \mathrm{L}\right) \mathrm{using}^{\mathrm{Cu}} \mathrm{Cu}_{2} \mathrm{O} / \mathrm{BiVO}_{4}$ under visible-light irradiation. (c) Band-gap structures of $\mathrm{Cu}_{2} \mathrm{O}$ and $\mathrm{BiVO}_{4}$, and the possible process for the separation of charge carriers [47].

dyes and reduction of $\mathrm{Cr}$ (VI) under visible light (Fig. 4(a) and (b)). With the matching of the band-gap energy between $\mathrm{Cu}_{2} \mathrm{O}$ and $\mathrm{BiOV}_{4}$, there is an efficient separation of charge carriers in the catalyst (Fig. 4(c)). Therefore, the photocatalytic oxidation of organics on the valance band of $\mathrm{Cu}_{2} \mathrm{O}$ and the photocatalytic reduction of $\mathrm{Cr}(\mathrm{VI})$ on the conduction band of $\mathrm{BiVO}_{4}$ occur concurrently. This is the first report on the simultaneous removal of organic and inorganic pollutants from waste water under a neutral condition.

\subsection{Heterojunctions between two bismuth-containing semiconductors}

Different bismuth-containing semiconductors have similar layered structures, which makes the preparation of heterojunctions between two bismuth-containing photocatalysts easy. Many composite photocatalysts of this kind have been reported in recent years; e.g., $\mathrm{Bi}_{2} \mathrm{O}_{3}-\mathrm{BiVO}_{4}$ [50-52], $\mathrm{Bi}_{2} \mathrm{O}_{3}-\mathrm{Bi}_{2} \mathrm{WO}_{6}$ [53], $\mathrm{Bi}_{2} \mathrm{O}_{3} / \mathrm{Bi}_{2} \mathrm{SiO}_{5}$ [54], $\mathrm{BiOBr} / \mathrm{Bi}_{24} \mathrm{O}_{31} \mathrm{Br}_{10}$ [55], $\mathrm{BiOI} / \mathrm{BiOBr}$ and $\mathrm{BiOCl} / \mathrm{BiOI}$ [56,57], $\mathrm{BiOCl} / \mathrm{BiVO}_{4}$ [58], $\mathrm{BiOI} / \mathrm{Bi}_{2} \mathrm{O}_{2} \mathrm{CO}_{3}[59,60]$, $\mathrm{Bi}_{2} \mathrm{O}_{3}-\mathrm{Bi}_{2} \mathrm{~S}_{3}$ [61,62], $\mathrm{BiVO}_{4} / \mathrm{Bi}_{2} \mathrm{O}_{2} \mathrm{CO}_{3}$ [63], and $\mathrm{Bi}_{2} \mathrm{O}_{2} \mathrm{CO}_{3} /$ $\mathrm{Bi}_{2} \mathrm{MoO}_{6}$ [64], $\mathrm{BiOI} / \mathrm{Bi}_{2} \mathrm{WO}_{6}$ [65], $\beta-\mathrm{Bi}_{2} \mathrm{O}_{3}-\mathrm{BiOI}$ [66], $\mathrm{Bi}-$ $\mathrm{OI} / \mathrm{Bi}_{2} \mathrm{MoO}_{6}$ [67] and $\mathrm{BiVO}_{4} / \mathrm{Bi}_{2} \mathrm{WO}_{6}$ [68].

Like the phase junction between anatase and rutile $\mathrm{TiO}_{2}$ reported by $\mathrm{Li}$ et al. [12], $\alpha-\beta$ phase heterojunctions on $\mathrm{Bi}_{2} \mathrm{O}_{3}$ nanowires were synthesized employing an in situ hydrothermal method $[69,70]$. Owing to the difference between their valance bands and conduction bands, photogenerated charge carriers can transfer along the phase junction and thus be separated efficiently. Since it is commonly regarded that the structure and exposure of active facets are influential in photocatalytic processes, the construction of composite photocatalysts with novel structures has become a hot topic. As a typical $p$-type semiconductor, $\mathrm{Bi}_{2} \mathrm{O}_{3}$ is widely used to form $p$ - $n$ heterojunctions with $n$-type semiconductors. Our group [52], by using L-lysine as the structure directing agent and by controlling the Bi to $\mathrm{V}$ molar ratio of the precursor, prepared peanut-like $\mathrm{BiVO}_{4}$ and $p-n \mathrm{Bi}_{2} \mathrm{O}_{3}-\mathrm{BiVO}_{4}$ that are hollow and porous. Although the band-gap energies of $\mathrm{Bi}_{2} \mathrm{O}_{3}$ and $\mathrm{BiVO}_{4}$ cannot enhance the charge transfer directly, the Fermi level of $\mathrm{Bi}_{2} \mathrm{O}_{3}$ is close to the valance band while that of $\mathrm{BiVO}_{4}$ is close to the conduction band. As illustrated in Fig. 5, the Fermi levels have similar values when $p$-type $\mathrm{Bi}_{2} \mathrm{O}_{3}$ and $n$-type $\mathrm{BiVO}_{4}$ come into contact with each other. That is to say, with the formation of $p$ - $n$ junctions, the energy bands of $\mathrm{Bi}_{2} \mathrm{O}_{3}$ shift upward along the Fermi level while those of $\mathrm{BiVO}_{4}$ shift downward. Along the $p$ - $n$ junctions and promoted by the inner electric field, photogenerated electrons and holes can be separated efficiently and the composite thus shows enhanced photocatalytic activity for dye degradation under visible light. A novel photocatalyst of a one-dimensional $\mathrm{Bi}_{2} \mathrm{O}_{3}$ nanorod- $\mathrm{Bi}_{2} \mathrm{WO}_{6}$ nanosheet with $p$ - $n$ junctions was prepared by Peng et al. [53] employing a three-step method. Owing to its novel structure and the light absorption efficiency, the composite has high activity towards dye degradation and water splitting. It was reckoned that the formation of $p-n$ junctions enhanced the separation of charge carriers, and the one-dimensional structure favors the transport of charges.

Among the reported bismuth-containing photocatalysts, $\mathrm{Bi}_{2} \mathrm{~S}_{3}$ (1.3-1.7 eV) and $\mathrm{BiOI}$ (1.7-1.9 eV) have relatively narrow band gaps. They have potential for use in visible-light-driven photocatalysis but the fast recombination of photogenerated electrons and holes is an inherent problem. Nevertheless, they are good visible-light sensitizer and can be used as a component for the formation of heterojunctions. $\mathrm{Bi}_{2} \mathrm{O}_{2} \mathrm{CO}_{3}$ is a semiconductor with a wide band gap of about $3.55 \mathrm{eV}$ and has good photocatalytic performance [71]. We combined BiOI with $\mathrm{Bi}_{2} \mathrm{O}_{2} \mathrm{CO}_{3}$ to form $p$ - $n$ heterojunctions [59]. As expected, the light absorption edge was red-shifted from 360 to $460 \mathrm{~nm}$ by introducing a trace amount of $\mathrm{BiOI}$ onto flower-like $\mathrm{Bi}_{2} \mathrm{O}_{2} \mathrm{CO}_{3}$. It is noted that the composite shows excellent activity and stability for the degradation of both a single dye and a mixture of dyes. Later, Cao et al. [60] prepared $\mathrm{BiOI} / \mathrm{Bi}_{2} \mathrm{O}_{2} \mathrm{CO}_{3}$ composites
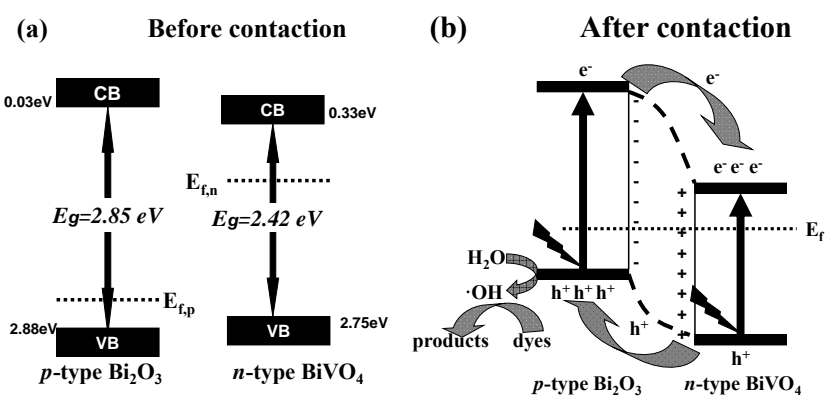

Fig. 5. Schematics of (a) the energy band of $\mathrm{Bi}_{2} \mathrm{O}_{3}$ and $\mathrm{BiVO}_{4}$ and (b) the formation of a $p-n$ junction and possible process for charges separation [52]. 
with $p-n$ junctions employing an in situ chemical etching method. Their results further confirmed that introducing BiOI onto $\mathrm{Bi}_{2} \mathrm{O}_{2} \mathrm{CO}_{3}$ results in broadening of the light absorption region and separation enhancement of charge carriers. Besides $\mathrm{Bi}_{2} \mathrm{O}_{2} \mathrm{CO}_{3}$, BiOI was also used to combine with visible-lightdriven semiconductors such as $\mathrm{Bi}_{2} \mathrm{WO}_{6}$. As reported by Xiang et al. [65], the formation of $p-n$ junctions between BiOI and $\mathrm{Bi}_{2} \mathrm{WO}_{6}$ not only greatly enhances the visible-light absorption ability but also improves the separation of charge carriers. Compared with pure $\mathrm{Bi}_{2} \mathrm{WO}_{6}$, pure $\mathrm{BiOI}$, and other $\mathrm{Bi}_{2} \mathrm{WO}_{6} / \mathrm{BiOI}$ composites, the composite has improved photocatalytic performance under visible-light irradiation. Almost all (99.99\%) of Pseudomonas Aeruginosa (P. aeruginosa), Escherichia Coli (E. coli) and Staphylococcus Aureus (S. aureus) were killed and the degradation efficiency of MB reached $100 \%$ within $60 \mathrm{~min}$ in the presence of $30 \% \mathrm{Bi}_{2} \mathrm{WO}_{6} / \mathrm{BiOI}$. Using $\mathrm{Bi}_{2} \mathrm{~S}_{3}$ instead of $\mathrm{BiOI}$, the as-prepared $\mathrm{Bi}_{2} \mathrm{~S}_{3}-\mathrm{Bi}_{2} \mathrm{O}_{2} \mathrm{CO}_{3}$ composite shows performance similar to that of $\mathrm{BiOI} / \mathrm{Bi}_{2} \mathrm{O}_{2} \mathrm{CO}_{3}[72]$.

Considering that $\mathrm{Bi}_{2} \mathrm{O}_{3}$ and $\mathrm{Bi}_{2} \mathrm{~S}_{3}$ are similar in structure but incommensurable in solubility $\left(K_{\mathrm{sp}}: 4 \times 10^{-31}\right.$ and $1 \times 10^{-97}$, respectively), we developed an etching and regrowth process for the preparation of hollow and branched $\mathrm{Bi}_{2} \mathrm{O}_{3}-\mathrm{Bi}_{2} \mathrm{~S}_{3}$ composite [62]. The two-step hydrothermal preparation method involves no organic solvent and/or structure directing agent (Fig. 6). First, $\mathrm{Bi}_{2} \mathrm{O}_{3}$ microtubes are synthesized employing a simple hydrothermal method and $\mathrm{Bi}\left(\mathrm{NO}_{3}\right)_{3} \cdot 5 \mathrm{H}_{2} \mathrm{O}$ as the precursor, and the microtubes are then treated in a S-containing solution to achieve $\mathrm{Bi}_{2} \mathrm{O}_{3}-\mathrm{Bi}_{2} \mathrm{~S}_{3}$. By varying the kind of $\mathrm{S}$ sources, the structure of $\mathrm{Bi}_{2} \mathrm{~S}_{3}$ on the surface of $\mathrm{Bi}_{2} \mathrm{O}_{3}$ changes but is always single-crystalline in nature. Because of the sensitization of $\mathrm{Bi}_{2} \mathrm{~S}_{3}$ and the branched structure, there is a broadening of the light absorption region and enhancement of light absorption over the composites. Therefore, the visible-light-excited photocurrent response of the composite is much higher than that of the components. Consequently, there is efficient separation of charge carriers at the heterojunctions and high photocatalytic activity for dye degradation. The separation efficiency of charge carriers in the composite is higher than that in $\mathrm{Bi}_{2} \mathrm{~S}_{3}$ or $\mathrm{Bi}_{2} \mathrm{O}_{3}$ as confirmed by room-temperature photoluminescence analysis.

Besides binary heterostructured composites, there are ternary heterostructured composites [73-76]. For example, Zou et al. [73] prepared ternary heterostructured $\mathrm{TiO}_{2}-\mathrm{Bi}_{2} \mathrm{MoO}_{6}-$ $\mathrm{Bi}_{3.64} \mathrm{Mo}_{0.36} \mathrm{O}_{6.55}$ employing a one-step solvothermal method. The photocatalytic activities of all the individual components and the binary composites were also investigated. As expected, the ternary composite performed much better than the others. The authors ascribed this to the efficient separation of charge carriers in the ternary composites, and proposed a possible process for the transfer of charges.

For both binary and ternary heterojunctions, charge separation along the junctions is enhanced and the transfer direction of electrons and holes locked owing to the presence of the Schottky barrier and the inner electric field. According to the basic principle of photocatalysis, if the photogenerated charges can be transported and separated as soon as they are generated, there is enhanced photocatalytic activity.

\section{Heterojunctions between bismuth-containing semiconductor and carbon/carbon-based materials}

\subsection{Graphene modification of bismuth-containing photocatalysts}

The use of graphene or reduced graphene oxide is a hot topic owing to their unique properties such as an extremely high specific surface area, high conductivity, super electron mobility and good electron trapping ability. Most recently, these carbon materials were employed as a structure-directing agent, photogenerated electron transfer channel, light absorption sensitizer and reactant adsorbent in photocatalysis [77]. Tu et al. [78] synthesized BiOBr-graphene composite employing an in situ method and graphene as the precursor. After

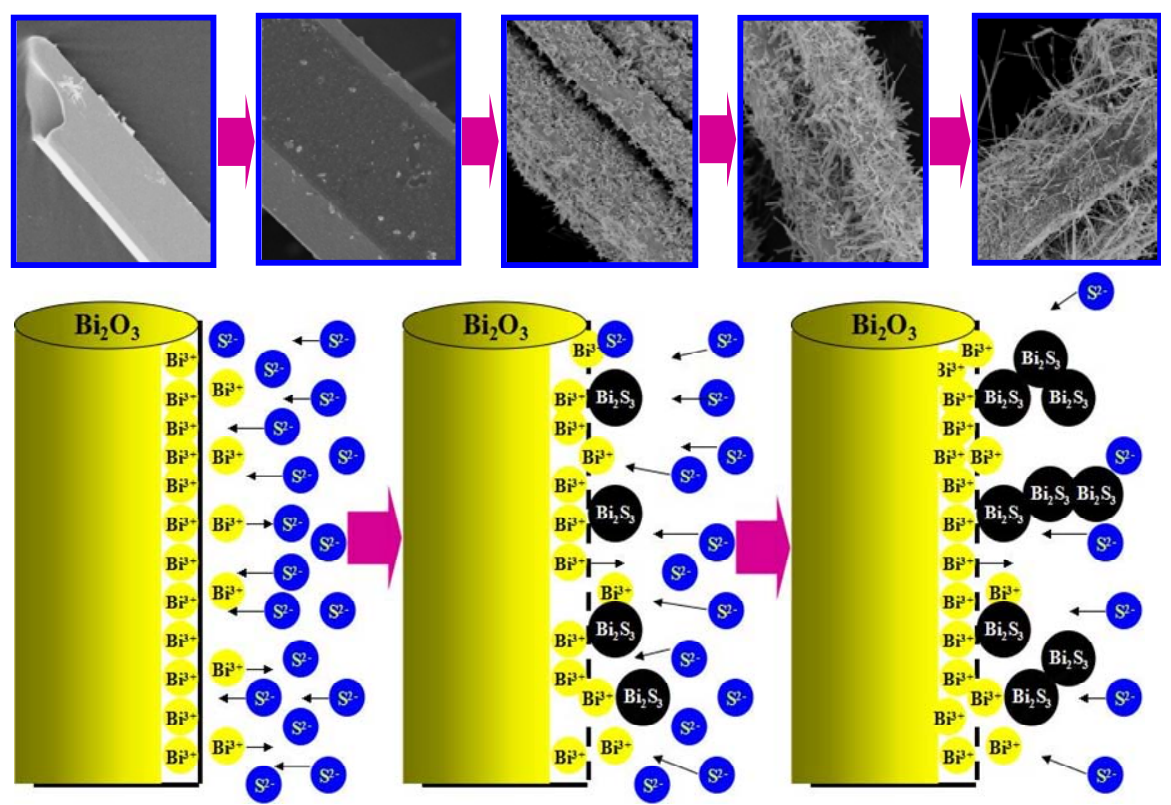

Fig. 6. Etching and regrowth mechanism proposed for the preparation of hollow and branched $\mathrm{Bi}_{2} \mathrm{O}_{3}-\mathrm{Bi}_{2} \mathrm{~S}_{3}$ composite [62]. 
combination with graphene, there was $40-\mathrm{nm}$ red shift on the light absorption edge, an approximately 20\% increase in dye (RhB) adsorption (compared with that of BiOBr), and a 2-fold increase in the degradation rate (according to the degradation rate constant). Gupta et al. [79] found that the modification of $\mathrm{Bi}_{2} \mathrm{Ti}_{2} \mathrm{O}_{7}$ with a proper amount of graphene not only enhances the photocatalytic activity by enhancing light absorption and charge carrier separation but also allows the formation of a structure of $\mathrm{Bi}_{2} \mathrm{Ti}_{2} \mathrm{O}_{7} /$ graphene having high stability. Works of this kind on the preparation of $\mathrm{Bi}_{2} \mathrm{Fe}_{4} \mathrm{O}_{9} / \mathrm{RGO}$ [80-82], Bi-

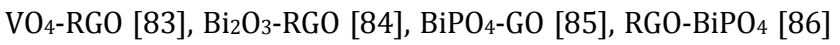
and BiOI-GO [87] were reported in recent years. However, for all these composites, the RGO or graphene amount has to be optimized with respect to the amount of Bi-containing semiconductor. Too high a graphene amount results in the active sites of photocatalysts being covered, reducing the photocatalytic activity.

\subsection{Polymer modification of Bi-containing photocatalysts}

Because of their unique electrical and optical properties, polymers (especially conductive polymers) are widely combined with semiconductors for the construction of efficient photocatalysts $[88,89]$. Taking polypyrrole (PPy) as an example, the polymer has high absorption coefficients in the visible-light region, high mobility of charge carriers and excellent stability [90,91]. Most importantly, unlike graphene and other carbon-based materials, PPy is also an efficient electron donor and good hole transporter upon visible-light irradiation. Recently, Zhang et al. [92] reported a $\mathrm{PPy} / \mathrm{Bi}_{2} \mathrm{WO}_{6}$ composite that has much higher photocatalytic activity for phenol degradation under simulated sunlight irradiation (Fig. 7(a)). The high photocatalytic activity could be explained by the good contact of PPy with $\mathrm{Bi}_{2} \mathrm{WO}_{6}$ that facilitates the separation of charge carriers, promoting the transfer of holes to the PPy/solution interface at a rate much higher than that for the self-oxidation of $\mathrm{Bi}_{2} \mathrm{WO}_{6}$ (Fig. 7(b)).

\section{3. $g$ - $C_{3} N_{4}$ combined with bismuth-containing photocatalysts}

Since the first report on the use of graphite-like carbon nitride $\left(g-\mathrm{C}_{3} \mathrm{~N}_{4}, E_{\mathrm{g}} \approx 2.7 \mathrm{eV}\right)$ for hydrogen production from water splitting under visible-light irradiation [93], the use of $\mathrm{C}_{3} \mathrm{~N}_{4}$ in photocatalysis has attracted great attention. $g-\mathrm{C}_{3} \mathrm{~N}_{4}$ materials can be synthesized from a simple precursor via a series of polycondensation reactions without any metal involvement. Unlike other metal-containing photocatalysts, $g-\mathrm{C}_{3} \mathrm{~N}_{4}$ is a sustainable and environmentally benign organic semiconductor. It is thermally and photochemically stable owing to the high degree of polymerization and $\pi$-conjugated structure [94-98]. However, $g-\mathrm{C}_{3} \mathrm{~N}_{4}$ by itself suffers from the high recombination of photogenerated electrons and holes. To improve its photocatalytic activity, $g-\mathrm{C}_{3} \mathrm{~N}_{4}$ has to be combined with a semiconductor for the construction of heterostructures. In recent years, there have been many reports on the combination of $\mathrm{g}-\mathrm{C}_{3} \mathrm{~N}_{4}$ with bismuth-containing photocatalysts; e.g., $g-\mathrm{C}_{3} \mathrm{~N}_{4} / \mathrm{BiVO}_{4}$ [99], $g-\mathrm{C}_{3} \mathrm{~N}_{4}$ - $\mathrm{BiOCl}$ [100], $g-\mathrm{C}_{3} \mathrm{~N}_{4}-\mathrm{Bi}_{2} \mathrm{WO}_{6}$ [101], $g-\mathrm{C}_{3} \mathrm{~N}_{4}-\mathrm{BiOBr}$ [102], $g-\mathrm{C}_{3} \mathrm{~N}_{4} / \mathrm{BiFeO}_{3}$ [103], $g-\mathrm{C}_{3} \mathrm{~N}_{4}-\mathrm{Bi}_{2} \mathrm{O}_{2} \mathrm{CO}_{3}$ [104] and $\beta-\mathrm{Bi}_{2} \mathrm{O}_{3}-$ $g-\mathrm{C}_{3} \mathrm{~N}_{4}$ [105]. All of these composites have higher activity than their components. Among them, $\mathrm{BiVO}_{4}$ decorated with $g-\mathrm{C}_{3} \mathrm{~N}_{4}$ nano-islands (5-10 $\mathrm{nm}$ ) has enhanced activity towards $\mathrm{MB}$ degradation and the authors ascribed the good performance to factors such as the full exposure of reaction sites, separation of redox reaction sites, and high separation rate of charge carriers at the heterojunctions [99]. Later by first-principle calculation, Zhang et al. [106] found that $g-\mathrm{C}_{3} \mathrm{~N}_{4} / \mathrm{BiVO}_{4}$ composites, especially those with heterojunctions between the (001) facet of $g-\mathrm{C}_{3} \mathrm{~N}_{4}$ and the (010) facet of $\mathrm{BiVO}_{4}$, showed enhanced visible-light-driven activity.

Our group has fabricated heterojunctions between $g-\mathrm{C}_{3} \mathrm{~N}_{4}$ and $\mathrm{Bi}_{2} \mathrm{O}_{2} \mathrm{CO}_{3}$ and used the composite for the degradation of organic dyes under visible light [104]. We found that the synergism of heterojunctions and dye sensitization results in enhanced catalytic activity (Fig. 8). Interestingly, when the $g-\mathrm{C}_{3} \mathrm{~N}_{4}-\mathrm{Bi}_{2} \mathrm{O}_{2} \mathrm{CO}_{3}$ composite was calcined at $400{ }^{\circ} \mathrm{C}$, the $\beta-\mathrm{Bi}_{2} \mathrm{O}_{3}-g-\mathrm{C}_{3} \mathrm{~N}_{4}$ composite formed [105]. It is noted that the calcination of $\mathrm{Bi}_{2} \mathrm{O}_{2} \mathrm{CO}_{3}$ at $400{ }^{\circ} \mathrm{C}$ in the absence of $g-\mathrm{C}_{3} \mathrm{~N}_{4}$ does not result in the generation of pure-phase $\beta-\mathrm{Bi}_{2} \mathrm{O}_{3}$, indicating the unique role of $g-\mathrm{C}_{3} \mathrm{~N}_{4}$ in directing the phase structure of $\mathrm{Bi}_{2} \mathrm{O}_{3}$ during calcination. This is the first report that $\mathrm{g}-\mathrm{C}_{3} \mathrm{~N}_{4}$ can act as a phase regulating agent. Furthermore, the $\beta-\mathrm{Bi}_{2} \mathrm{O}_{3}$ $g$ - $\mathrm{C}_{3} \mathrm{~N}_{4}$ composite shows high photocatalytic activity even for the degradation of 2,4-dichlorophenol, which is known to have no visible-light absorption ability.

It should be noted that the combination of semiconductors affects the band-gap energy (i.e., redox abilities) of the compo-
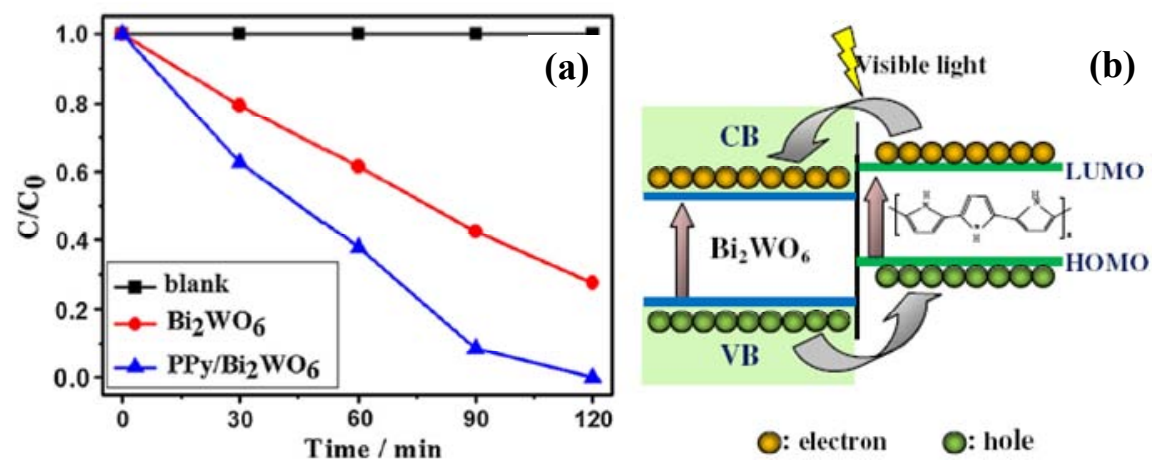

Fig. 7. (a) Degradation efficiency of phenol as a function of time for the as-prepared samples under visible-light irradiation. (b) Energy level diagram of $\mathrm{Bi}_{2} \mathrm{WO}_{6}$ and PPy and the charge transfer processes [92]. 


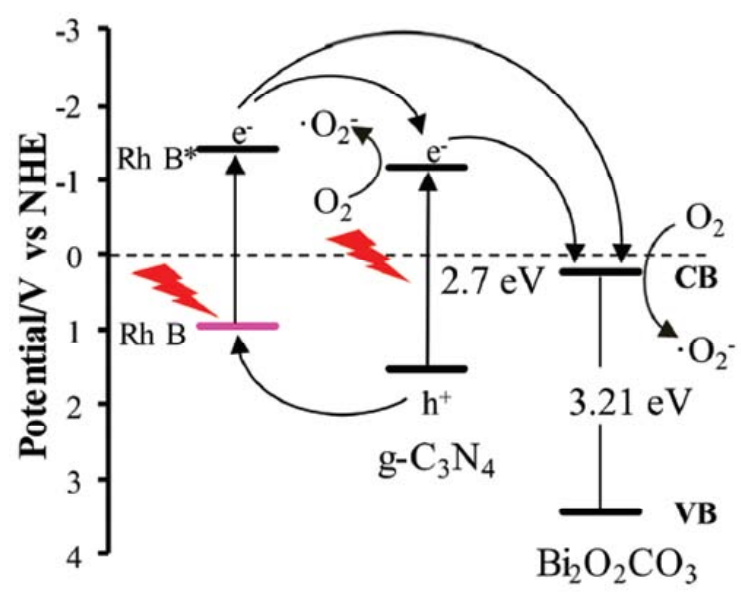

Fig. 8. Possible mechanism of charge separation and photocatalytic process over $g$ - $\mathrm{C}_{3} \mathrm{~N}_{4}-\mathrm{Bi}_{2} \mathrm{O}_{2} \mathrm{CO}_{3}$ under visible-light irradiation [104].

site, but the band gaps of the individual components do not changed. That is to say, the natural physical property of a semiconductor is unaffected by the combination of semiconductors.

\section{Doping of Bi-containing photocatalysts}

In recent years, there has been much work on the doping of semiconductors using metals or nonmetals. The doping of heteroatoms broadens the light absorption ability and enhances structure stability during the photocatalytic process.

\subsection{Metal doping}

Many reports revealed that the doping of metal ions into bismuth-containing photocatalysts resulted in enhanced activity [107-113]. Furthermore, the doping of metal ions also stabilizes the composites. For example, Wang and co-workers [114] reported that the doping of titanium ions into $\beta-\mathrm{Bi}_{2} \mathrm{O}_{3}$ could prevent the conversion to $\mathrm{Bi}_{2} \mathrm{O}_{2} \mathrm{CO}_{3}$ in the photocatalytic process. Colon and co-workers [115] then reported that, with the doping of $\mathrm{Er}^{3+}$ into the lattice of $\mathrm{BiVO}_{4}$ even in a trace amount, the fabrication of heterojunctions between monoclinic $\left(m-\mathrm{BiVO}_{4}\right)$ and tetragonal $\left(t-\mathrm{BiVO}_{4}\right) \mathrm{BiVO}_{4}$ could be achieved in a controlled manner. As the amount of Er doping increased from 0 to 10 at $\%$, there was a gradual transfer of $m$-BiVO 4 to $t$ - $\mathrm{BiVO}_{4}$. At 0.75 at\% Er doping, the as-prepared Er- $m$ - $t$-BiVO showed the highest photocatalytic activity for MB degradation and $\mathrm{O}_{2}$ evolution from water splitting (Fig. 9) [115,116]. Additionally, Zhou et al. [117] reported that the doping of $\mathrm{Er}^{3+}$ into $\mathrm{Bi}_{2} \mathrm{MoO}_{6}$ affects the final morphology of $\mathrm{Bi}_{2} \mathrm{MoO}_{6}$ and greatly enhances the activity for dye and phenol degradation.

Besides doping with a single kind of ion, doping with more than one kind of ion has been studied. The synergistic effect of doping with two or more kinds of ions was also investigated. For example, Nussbaum et al. [118] reported the co-doping of $\mathrm{BiOCl}$ with $\mathrm{Fe}$ and $\mathrm{Nb}$ ions. It was observed that even at low contents of $\mathrm{Fe}$ and $\mathrm{Nb}$ doping, the composite showed much higher activity than the components and the composites doped with a single kind of ion. A similar phenomenon was reported by Zhou et al. [119], who used W and Mo ions to co-dope $\mathrm{BiVO}_{4}$.

\section{2. $\quad$ Nonmetal doping}

Nonmetal (most commonly carbon) doping is usually employed to narrow the band gap of semiconductors and thus improve the visible-light response, just as ever reported to enhance the visible-light absorption of $\mathrm{TiO}_{2}$ by $\mathrm{C}$ doping [120]. Doping Bi-containing photocatalysts with carbon also produces such an effect. Yin et al. [121] fabricated C-doped $\mathrm{BiOV}_{4}$ using a one-step method. They reported that due to the presence of $\mathrm{C}$ in the lattice of $\mathrm{BiVO}_{4}$, there was high activity towards dye degradation and water splitting for $\mathrm{O}_{2}$ evolution under visible-light irradiation. The main reason for this was the extension of the light absorption edge from 480 to $700 \mathrm{~nm}$. Homoplastically, the carbon doping of $\mathrm{Bi}_{2} \mathrm{O}_{3}$ and $\mathrm{BiVO}_{4}$ can greatly enhance visible-light-driven activity [122,123].

\section{Bi-metal-modified photocatalysts}

Bismuth is a semimetal that has a very small band overlap and possesses an interesting SPR property [124]. Given the high price of noble metals, inexpensive $\mathrm{Bi}$ with its unique properties can be used as an alternative in the SPR photocatalytic process. The synthesis of Bi-modified photocatalysts has aroused intense interest [125-127]. Most recently, Dong and co-workers [128] used Bi metal as a co-catalyst on the surface

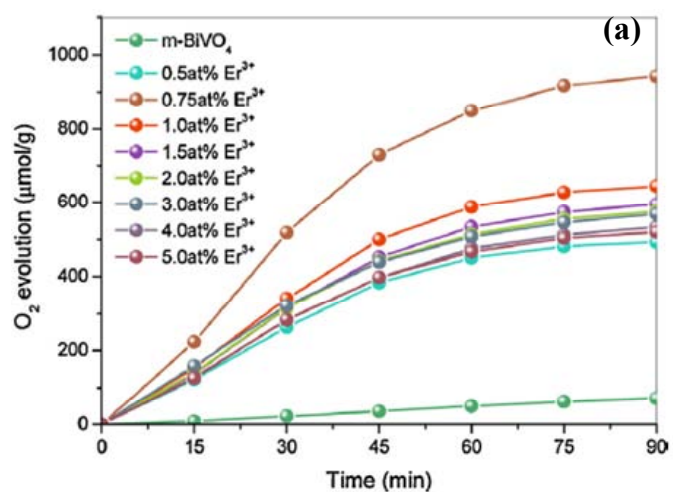

(b)

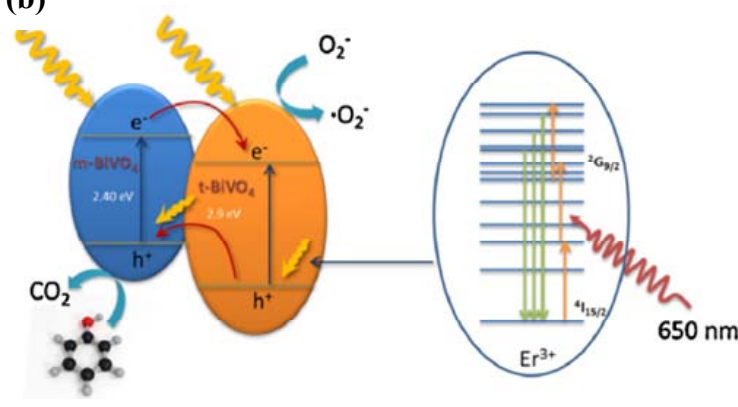

Fig. 9. (a) Photocatalytic $\mathrm{O}_{2}$ evolution from aqueous $\mathrm{AgNO}_{3}$ solutions $(0.02 \mathrm{~mol} / \mathrm{L})$ in the $\mathrm{Er}^{3+}-\mathrm{BiVO}_{4}$ system as a function of irradiation time. (b) Envisaged electronic scheme involved in the photocatalytic mechanism upon solar-like excitation [116]. 


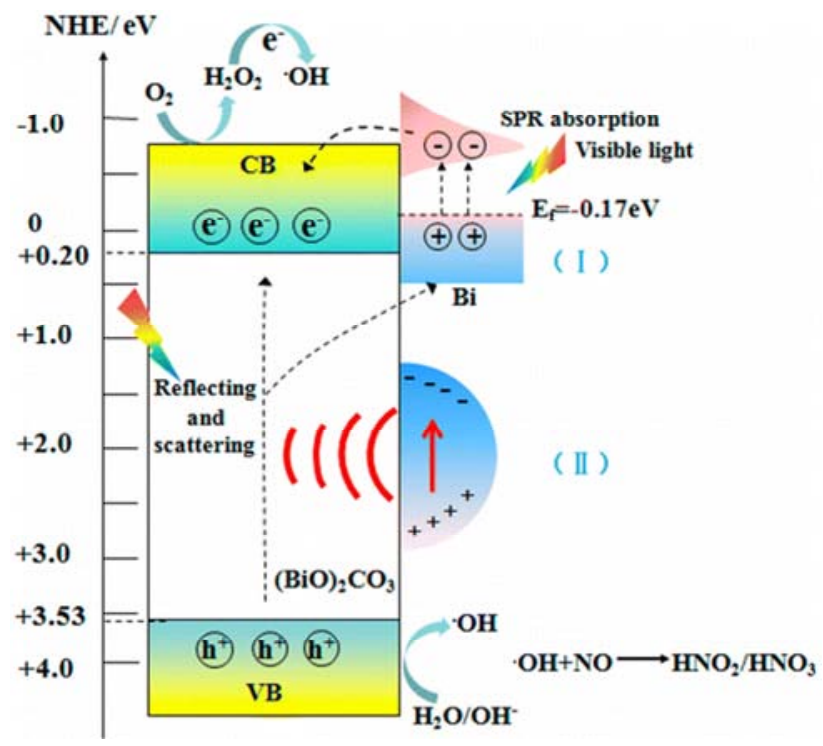

Fig. 10. Photocatalytic mechanism of $\mathrm{Bi} /(\mathrm{BiO})_{2} \mathrm{CO}_{3}$ under visible-light irradiation: interface transfer of electrons from $(\mathrm{BiO})_{2} \mathrm{CO}_{3}$ to $\mathrm{Bi}(\mathrm{I})$ and the local electromagnetic field of $\mathrm{Bi}(\mathrm{II})$ [128].

of $\mathrm{Bi}_{2} \mathrm{O}_{2} \mathrm{CO}_{3}$ microspheres and the composites showed enhanced activity for NO removal under visible-light irradiation at different intensities. They demonstrated that the enhancement of photocatalytic activity of $\mathrm{Bi}_{2} \mathrm{O}_{2} \mathrm{CO}_{3}$ could be ascribed to the SPR effect of $\mathrm{Bi}$ and to the fact that $\mathrm{Bi}$ metal on the $\mathrm{Bi}_{2} \mathrm{O}_{2} \mathrm{CO}_{3}$ surface can prolong the lifetime of charge carriers (Fig. 10). The phenomenon is in agreement with the SPR effect of a noble metal. Unfortunately, the stability of the as-prepared samples was not investigated. Bi metal is commonly known to be unstable under atmospheric conditions because it readily oxidizes into $\mathrm{Bi}_{2} \mathrm{O}_{3}$.

\section{Conclusions and perspectives}

With unique physicochemical properties, bismuth-containing photocatalysts are endowed with excellent visible-light responses. Unfortunately, the photocatalytic activity is still unsatisfactory owing to the recombination of photogenerated charge carriers. To improve photocatalytic activity, strategies such as loading with a noble metal, the generation of heterojunctions through combination with a semiconductor, modification with carbon-based materials, doping with heteroatoms and modification with Bi metal have been adopted. Although significant progress has been made, further efforts are required to further advance the use of this class of photocatalysts (especially those with heterojunctions). Three aspects are of special relevance.

(1) Throughout the literature, the application of bismuth-containing photocatalysts with heterojunctions mainly focused on the degradation of organic pollutants, and only a few studies focused on water splitting and $\mathrm{CO}_{2}$ reduction. The generation of $Z$-scheme heterojunctions between bismuth-containing photocatalysts and semiconductors of more negative $\mathrm{CB}$ could be promising for the preparation of efficient visible-light-driven composites for the generation of $\mathrm{H}_{2}$ from water splitting and fuel production from $\mathrm{CO}_{2}$ reduction.

(2) Owing to the positive VB edges, bismuth-containing photocatalysts commonly show relatively high activity for oxidation reactions. In our previous study, $\mathrm{Bi}_{2} \mathrm{WO}_{6}$ showed high activity and selectivity for the oxidation of saturated alpha-carbon (i.e., $\mathrm{C}-\mathrm{H}$ bonds) in aromatic alkanes at room temperature under solvent-free conditions [129]. After adjusting the band-gap energy of $\mathrm{Bi}_{2} \mathrm{WO}_{6}$ through combination with semiconductors, the as-prepared composites could be used for the selective oxidation of organics to produce fine chemicals. Photocatalytic organic synthesis conducted under mild conditions has a great potential owing to the green energy and mild conditions involved.

(3) The design and fabrication of nonstoichiometric bismuth-containing photocatalysts is a potential method of adjusting the band-gap structures and constructing defects as well as oxygen vacancies. Importantly, it is envisaged that, besides the enrichment of active sites, the presence of defects and oxygen vacancies on the surface of a catalyst is essential for the enhanced separation of charge carriers. Additionally, the fabrication of nonstoichiometric bismuth-containing materials could be a feasible way of further enhancing the visible-light-driven activity of this class of photocatalysts.

\section{Acknowledgments}

Chak-Tong Au thanks the Hunan University for an adjunct professorship.

\section{References}

[1] W. Wang, M. O. Tade, Z. P. Shao, Chem. Soc. Rev., 2015, 44, 5371-5408.

[2] C. L. Yu, W. Q. Zhou, J. C. Yu, H. Liu, L. F. Wei, Chin. J. Catal., 2014, 35, 1609-1618.

[3] X. J. Lang, X. D. Chen, J. C. Zhao, Chem. Soc. Rev., 2014, 43, 473-486.

[4] H. H. Chen, C. F. Nanavakkara, V. H. Grassian, Chem. Rev., 2012, 112, 5919-5948.

[5] L. Shi, W. J. Xia, Chem. Soc. Rev., 2012, 41, 7687-7697.

[6] C. P. Wu, Y. Zhou, Z. G. Zou, Chin. J. Catal., 2011, 32, 1565-1572.

[7] A. Fujishima, K. Honda, Nature, 1972, 238, 37-38.

[8] T. Froeschl, U. Hoermann, P. Kubiak, G. Kucerova, M. Pfanzelt, C. K. Weiss, R. J. Behm, N. Husing, U. Kaiser, K. Landfester, Chem. Soc. Rev., 2012, 41, 5313-5360.

[9] H. Tada, M. Fujishima, H. Kobayashi, Chem. Soc. Rev., 2011, 40, $4232-4243$.

[10] R. A. He, S. W. Cao, P. Zhou, J. G. Yu, Chin. J. Catal., 2014, 35, 989-1007.

[11] X. Zong, H. J. Yan, G. P. Wu, G. J. Ma, F. Y. Wen, L. Wang, C. Li, J. Am. Chem. Soc., 2008, 130, 7176-7177.

[12] J. Zhang, Q. Xu, Z. C. Feng, M. J. Li, C. Li, Angew. Chem. Int. Ed., 2008, $120,1766-1769$.

[13] H. L. Wang, L. S. Zhang, Z. G. Chen, J. Q. Hu, S. J. Li, Z. H. Wang, J. S. Liu, X. C. Wang, Chem. Soc. Rev., 2014, 43, 5234-5244.

[14] J. C. Colmenares, R. Luque, Chem. Soc. Rev., 2014, 43, 765-778.

[15] Y. Q. Qu, X. F. Duan, Chem. Soc. Rev., 2013, 42, 2568-2580.

[16] G. Baffou, R. Quidant, Chem. Soc. Rev., 2014, 43, 3898-3907.

[17] G. Manna, R. Bose, N. Pradhan, Angew. Chem. Int. Ed., 2014, 53, 6743-6746. 
[18] M. Qamar, R. B. Elsayed, K. R. Alhooshani, M. I. Ahmed, D. W. Bahnemann, ASC Appl. Mater. Interfaces, 2015, 7, 1257-1269.

[19] B. F. Luo, D. B. Xu, G. L. Wu, M. M. Wu, W. D. Shi, M. Chen, ASC Appl. Mater. Interfaces, 2015, 7, 17061-17069.

[20] F. Dong, Q. Y. Li, Y. Zhou, Y. J. Sun, H. D. Zhang, Z. B. Wu, Dalton Trans., 2014, 43, 9468-9480.

[21] M. H. Fulekar, A. Singh, D. P. Dutta, M. Roy, A. Ballal, A. K. Tyagi, RSC Adv., 2014, 4, 10097-10107.

[22] C. L. Yu, F. F. Cao, G. Li, R. F. Wei, J. C. Yu, R. C. Jin, Q. Z. Fan, C. Y. Wang, Sep. Purf. Technol., 2013, 120, 110-122.

[23] Y. N. Guo, L. Chen, F. Y. Ma, S. Q. Zhang, Y. X. Yang, X. Yuan, Y. H. Gao, J. Hazard. Mater., 2011, 189, 614-618.

[24] X. D. Wang, G. I. N. Waterhouse, D. R. G. Mitchell, K. Price, R. A. Caruso, ChemCatChem, 2011, 3, 1763-1771.

[25] X. F. Zhang, Y. B. Zhang, X. Quan, S. Chen, J. Hazard. Mater., 2009, 167, 911-914.

[26] L. Chen, R. Huang, Y. J. Ma, S. L. Luo, C. T. Au, S. F. Yin, RSC Adv., 2013, 3, 24354-24361.

[27] D. Y. Li, Y. G. Zhang, Y. L. Zhang, X. F. Zhou, S. J. Guo, J. Hazard. Mater., 2013, 258-259, 42-49.

[28] B. Naik, N. K. M. Parida, G. C. Behera, ChemCatChem, 2011, 3 , 311-318.

[29] N. Li, L. Zhu, W. D. Zhang, Y. X. Yu, W. H. Zhang, M. F. Huo, J. Alloys Comp., 2011, 509, 9770-9775.

[30] L. Q. Jing, J. Wang, Y. C. Qu, Y. B. Luan, Appl. Surface Sci., 2009, 256 657-663.

[31] J. Lu, Z. S. Wang, Y. Zhang, X. F. Zhou, J. Nanomater., 2013, 125409.

[32] X. X. Wei, H. T. Cui, S. Q. Guo, L. F. Zhao, W. Li, J. Hazard. Mater., 2013, 263, 650-658.

[33] L. Li, X. D. Huang, J. Q. Zhang, W. Z. Zhang, F. Y. Ma, Z. X. Xiao, S. Gai, D. D. Wang, N. Li, J. Colloid Interface Sci., 2015, 443, 13-22.

[34] Y. Y. Yang, L. L. Xu, C. Y. Su, J. X. Che, W. J. Sun, H. Gao, J. Nanomater., 2014, 130539.

[35] C. J. Li, P. Zhang, R. Lv, J. W. Lu, T. Wang, S. P. Wang, H. F. Wang, J. L. Gong, Small, 2013, 9, 3951-3956.

[36] M. Y. Zhang, L. Li, Y. Liu, L. L. Xu, X. T. Zhang, J. Mol. Catal. A, 2015, $400,154-161$.

[37] Y. S. Xu, W. D. Zhang, Dalton Trans., 2013, 42, 1094-1101.

[38] L. Chen, J. He, M. Xiong, Q. Yuan, Y. W. Zhang, F. Wang, S. L. Luo, C. T. Au, S. F. Yin, RSC Adv., 2015, 5, 33747-33754.

[39] S. Shamaila, A. K. L. Sajjad, F. Chen, J. L. Zhang, J. Colloid Interface Sci., 2011, 356, 465-472.

[40] R. Q. Guo, L. Fang, W. Dong, F. G. Zheng, M. R. Shen, J. Mater. Chem. 2011, 21, 18645-18652.

[41] W. Ramadan, P. A. Shaikh, S. Ebrahim, A. Ramadan, B. Hannoyer, S. Jouen, X. Sauvage, S. Ogale, J. Nanopart. Res., 2013, 15, 1848/11848/10.

[42] J. Xu, W. Z. Wang, J. Wang, Y. J. Liang, Appl. Surface Sci., 2015, 349, 529-537.

[43] E. S. Kim, H. J. Kang, G. Magesh, J. Y. Kim, J. W. Jang, J. S. Lee, ACS Appl. Mater. Interfaces, 2014, 6, 17762-17769.

[44] W. Q. Cui, W. J. An, L. Liu, J. S. Hu, Y. H. Liang, J. Hazard. Mater., 2014, 280, 417-427.

[45] E. Aguilera-Ruiz , U. M. Garcia-Perez, M. De La Garza-Galvan, P. Zambrano-Robledo, B. Bermudez-Reyes, J. Peral, Appl. Surface Sci., 2015, 328, 361-367.

[46] H. Q. Li, W. S. Hong, Y. M. Cui, X. Y. Hu, S. H. Fan, L. J. Zhu, Mater. Sci. Eng. B, 2014, 181, 1-8.

[47] Q. Yuan, L. Chen, M. Xiong, J. He, S. L. Luo, C. T. Au, S. F. Yin, Chem Eng. J., 2014, 255, 394-402.

[48] R. G. Li, F. X. Zhang, D. E. Wang, J. X. Yang, M. R. Li, J. Zhu, X. Zhou, H. X. Han, C. Li, Nat. Commun., 2013, 4, 1432.
[49] H. Y. Li, Y. J. Sun, B. Cai, S. Y. Gan, D. X. Han, N. Li, T. S. Wu, Appl. Catal. B, 2015, 170-171, 206-214.

[50] M. L. Guan, D. K. Ma, S. W. Hu, Y. J. Chen, S. M. Huang, Inorg. Chem., 2011, 50, 800-805.

[51] Y. F. Cheng, H. Wang, Y. Zhu, F. Liao, Z. P. Li, J. K. Li, J. Mater. Sci.: Mater. Electron., 2015, 26, 1268-1274.

[52] L. Chen, Q. Zhang, R. Huang, S. F. Yin, S. L. Luo, C. T. Au, Dalton Trans., 2012, 41, 9513-9518.

[53] Y. Peng, M. Yan, Q. G. Chen, C. M. Fan, H. Y. Zhou, A. W. Xu, J. Mater Chem. A, 2014, 2, 8517-8524.

[54] L. Zhang, W. Z. Wang, S. M. Sun, D. Jiang, E. P. Gao, CrystEngComm, 2013, 15, 10043-10048.

[55] Z. S. Liu, H. S. Ran, J. N. Niu, P. Z. Feng, Y. B. Zhou, J. Colloid Interface Sci., 2014, 431, 187-193.

[56] T. B. Li, G. Chen, C. Zhou, Z. Y. Shen, R. C. Jin, J. X. Sun, Dalton Trans., 2011, 40, 6751-6758

[57] H. L. Lin, H. F. Ye, X. Li, J. Cao, S. F. Chen, Ceram. Int., 2014, 40, 9743-9750.

[58] J. Cao, C. C. Zhou, H. L. Lin, B. Y. Xu, S. F. Chen, Appl. Surface Sci,, 2013, 284, 263-269.

[59] L. Chen, S. F. Yin, S. L. Luo, R. Huang, Q. Zhang, T. Hong, C. T. Au, Ind. Eng. Chem. Res., 2012, 51, 6760-6768.

[60] J. Cao, X. Li, H. L. Lin, S. F. Chen, X. L. Fu, J. Hazard Mater., 2012 , 239-240, 316-324.

[61] Y. H. Yan, Z. X. Zhou, X. H. Zhao, J. G. Zhou, J. Colloid Interface Sci., 2014, 435, 91-98.

[62] L. Chen, J. He, Q. Yuan, Y. Liu, C. T. Au, S. F. Yin, J. Mater. Chem. A 2015, 3, 1096-1102.

[63] P. Madhusudan, J. R. Ran, J. Zhang, J. G. Yu, G. Liu, Appl. Catal. B, 2011, 110, 286-295.

[64] Y. S. Xu, Y. X. Yu, W. D. Zhang, J. Nanosci. Nanotechnol., 2014, 14 6800-6808.

[65] Y. H. Xiang, P. Ju, Y. Wang, Y. Sun, D. Zhang, J. G. Yu, Chem. Eng. J., 2016, 288, 264-275.

[66] S. Q. Han, J. Li, K. L. Yang, J. Lin, Chin. J. Catal., 2015, 36, 2119-2126.

[67] F. Chen, C. G. Niu, Q. Yang, X. M. Li, G. M. Zeng, Ceram. Int., 2016, $42,2515-2525$

[68] S. Xue, Z. W. Wei, X. Y. Huo, W. H. Xie, S. Y. Li, S. N. Shang, D. Y. H, Appl. Surf. Sci., 2015, 355, 1107-1115.

[69] Y. H. Yan, Z. X. Zhou, Y. Chen, L. L. Qiu, C. P. Gao, J. G. Zhou, J. Alloys Compouds, 2014, 605, 102-108.

[70] J. G. Huo, C. Yang, Z. Wang, W. L. Zhou, S. Q. Jiao, H. M. Zhu, Appl. Catal. B, 2013, 142-143, 504-511.

[71] L. Chen, R. Huang, S. F. Yin, S. L. Luo, C. T. Au, Chem. Eng. J., 2012, 193-194, 123-130.

[72] F. Dong, X. Feng, Y. X. Zhang, C. F. Gao, Z. B. Wu, RSC Adv., 2015, 5, 11714-11723.

[73] J. P. Zou, S. L. Luo, L. Z. Zhang, J. Ma, S. L. Lie, L. S. Zhang, X. B. Luo, Y. Luo, G. S. Zeng, C. T. Au, Appl. Catal. B, 2013, 140-141, 608-618.

[74] P. W. Lv, M. Zheng, X. Wang, F. Huang, J. Alloys Compounds, 2014, 583, 285-290.

[75] S. H. Chen, Z. Yin, S. L. Luo, C. T. Au, X. J. Li, Mater. Res. Bull, 2013 $48,725-729$.

[76] H. H. Gan, G. K. Zhang, Y. D. Guo, J. Colloid Interfaces Sci., 2012, 386, 373-380.

[77] X. Huang, X. Y. Qi, F. Boey, H. Zhang, Chem. Soc. Rev., 2012, 41, 666-686.

[78] X. M. Tu, S. L. Luo, G. X. Chen, J. H. Li, Chem. Eur. J., 2012, 18, 14359-14366.

[79] S. Gupta, V. Subramanian, ACS Appl. Mater. Interfaces, 2014, 6, 18597-18608. 
[80] Z. T. Hu, J. C. Liu, X. L. Yan, W. D. Oh, T. T. Lim, Chem. Eng. J., 2015, 262, 1022-1032.

[81] H. J. Sun, Y. Liu, Y. Zhang, L. Lv, J. Zhou, W. Chen, J. Mater. Sci.: Mater. Electron., 2014, 25, 4212-4218.

[82] J. F. Dai, T. Xian, L. J. Di, H. Yang, J. Nanomater., 2013, 642897.

[83] Q. H. Li, Y. B. Yuan, Z. H. Chen, X. Jin, T. H. Wei, Y. Li, Y. C. Qin, W. F. Sun, ACS Appl. Mater. Interfaces, 2014, 6, 12798-12806.

[84] X. J. Liu, L. K. Pan, T. Lv, Z. Sun, C. Q. Sun, J. Colloid Interface Sci., 2013, 408, 145-150.

[85] H. W. Lv, X. P. Shen, Z. Y. Ji, D. Z. Qiu, G. X. Zhu, Y. L. Bi, Appl. Surface Sci., 2013, 284, 308-314.

[86] C. Wang, G. H. Zhang, C. Zhang, M. M. Wu, M. Yan, W. Q. Fan, W. D. Shi, J Colloid Interface Sci., 2014, 435: 156-163.

[87] R. G. He, S. W. Cao, D. P. Guo, B. Cheng, S. Waneh, A. A. Al-Ghamdi, J. G. Yu, Ceram. Int., 2015, 41, 3511-3517.

[88] M. Shang, W. Z. Wang, S. M. Sun, J. Ren, L. Zhou, L. Zhang, J. Phys. Chem. C, 2009, 113, 20228-20233.

[89] P. M. Dziewonski, M. Grzeszczuk, Electrochim. Acta, 2010, 55, 3336-3347.

[90] H. C. Liang, X. Z. Li, Appl. Catal. B, 2009, 86, 8-17.

[91] Q. Z. Luo, X. Y. Li, D. S. Wang, Y. H. Wang, J. An, J. Mater. Sci., 2011, $46,1646-1654$

[92] Z. J. Zhang, W. Z. Wang, E. P. Gao, J. Mater. Sci., 2014, 49, 7325-7332.

[93] X. C. Wang, K. Maeda, A. Thomas, K. Takanabe, G. Xin, J. M. Carlsson, K. Domen, M. Antonietti, Nat. Mater., 2009, 8, 76-80.

[94] G. Liu, P. Niu, C. H. Sun, S. C. Smith, Z. G. Chen, G. Q. Lu, H. M. Cheng, J. Am. Chem. Soc., 2010, 132, 11642-11648.

[95] X. H. Li, X. C. Wang, M. Antonietti, Chem. Sci., 2012, 3, 2170-2174.

[96] Y. Wang, X. C. Wang, M. Antonietti, Angew. Chem. Int. Ed., 2012, $51,68-89$.

[97] T. T. Li, L. H. Zhao, Y. M. He, J. Cai, M. F. Luo, J. J. Lin, Appl. Catal. B, 2013, 129, 255-263.

[98] Y. L. Tian, B. B. Chang, J. L. Lu, J. Fu, F. N. Xi, X. P. Dong, ACS Appl. Mater. Interfaces, 2013, 5, 7079-7085.

[99] C. J. Li, S. P. Wang, T. Wang, Y. J. Wei, P. Zhang, J. L. Gong, Small, 2014, 10, 2783-2790.

[100] F. Chang, Y. C. Xie, J. Zhang, J. Chen, C. L. Li, J. Wang, J. R. Luo, B. Q. Deng, X. F. Hu, RSC Adv., 2014, 4, 28519-28528.

[101] W. Chen, T. Y. Liu, T. Huang, X. H. Liu, J. W. Zhu, G. R. Duan, X. J. Yang, Appl. Surface Sci., 2015, 355, 379-387.

[102] M. Q. He, D. X. Zhao, J. X. Xia, L. Xu, J. Di, H. Xu, S. Yin, H. M. Li, Ma- ter. Sci. Semcond. Process., 2015, 32, 117-124.

[103] X. F. Wang, W. W. Mao, J. Zhang, Y. M. Huan, C. Y. Quan, Q. X. Zhang, T. Yang, J. P. Yang, X. A. Li, W. Huang, J. Colloid Interface Sci., 2015, 448, 17-23.

[104] M. Xiong, L. Chen, Q. Yuan, J. He, S. L. Luo, C. T. Au, S. F. Yin, Dalton Trans., 2014, 43, 8331-8337.

[105] M. Xiong, L. Chen, Q. Yuan, J. He, S. L. Luo, C. T. Au, S. F. Yin, Carbon, 2015, 86, 217-224.

[106] J. H. Zhang, F. Z. Ren, M. S. Deng, Y. X. Wang, Phys. Chem. Chem. Phys., 2015, 17, 10218-10226.

[107] A. A. Alemi, R. Kashfi, B. Shabani, J. Mol. Catal. A, 2014, 392, 290-298.

[108] V. I. Merupo, S. Velumani, K. Ordon, N. Errien, J. Szade, A. H. Kassiba, CrystEngComm, 2015, 17, 3366-3375.

[109] C. Karunakaran, S. Kalaivani, P. Vinayagamoorthy, Mater. Exp., 2014, 4, 125-134.

[110] W. Xie, W. Hu, L. L. Zou, D. H. Bao, Ceram. Int., 2015, 41, S265-S273.

[111] J. F. Niu, S. Y. Ding, L. W. Zhang, J. B. Zhao, C. H. Feng, Chemosphere, 2013, 93, 1-8.

[112] L. F. Yin, J. F. Niu, Z. Y. Shen, J. Chen, Envorn. Sci. Technol., 2010, 44, 5581-5586.

[113] C. Karunakaran, S. Kalaivani, Mater. Sci. Semcond. Process., 2014, 27, 352-361.

[114] Y. Wang, Y. Y. Wen, H. M. Ding, Y. K. Shan, J. Mater. Sci., 2010, 45, 1385-1392.

[115] S. Usai, S. Obregon, A. I. Becerro, G. J. Colon, J. Phys. Chem. C, 2013, 117, 24479-24484.

[116] S. Obregon, G. Colon, Appl. Catal. B, 2014, 158-159, 242-249.

[117] T. F. Zhou, J. C. Hu, J. L. Li, Appl. Catal. B, 2011, 110, 221-230.

[118] M. Nussbaum, N. Shaham-Waldmann, Y. Paz, J. Photochem. Photobiol. A, 2014, 290, 11-21.

[119] Y. Zhou, W. Li, W. C. Wang, R. Y. Zhang, Y. H. Lin, Superlattices Microstruct., 2015, 82, 67-74.

[120] W. J. Ren, Z. H. Ai, F. L. Jia, L. Z. Zhang, X. X. Fan, Z. G. Zou, Appl. Catal. B, 2007, 69, 138-144.

[121] C. Yin, S. M. Zhu, Z. X. Chen, W. Zhang, J. J. Gu, D. Zhang, J. Mater. Chem. A, 2013, 1, 8367-8378.

[122] G. P. Dai, S. Q. Liu, Y. Liang, J. Alloys Comp., 2014, 608, 44-48.

[123] M. M. Yao, L. H. Gan, M. X. Liu, P. K. Tripathi, Y. F. Liu, Z. H. Hu, J. Mater. Eng. Perform., 2015, 24, 2359-2367.

[124] Z. B. Zhang, X. Z. Sun, M. S. Dresselhaus, J. Y. Ying, Phys. Rev. B,

\section{Graphical Abstract}

Chin. J. Catal., 2016, 37: 780-791 doi: 10.1016/S1872-2067(15)61061-0

\section{Recent advances in bismuth-containing photocatalysts with} heterojunctions

Lang Chen, Jie He, Ying Liu, Peng Chen, Chak-Tong Au,

Shuang-Feng Yin*

Hunan University

Recent achievements in bismuth-containing photocatalysts with heterojunctions were summarized and their future developments as well as their potential applications were discussed.

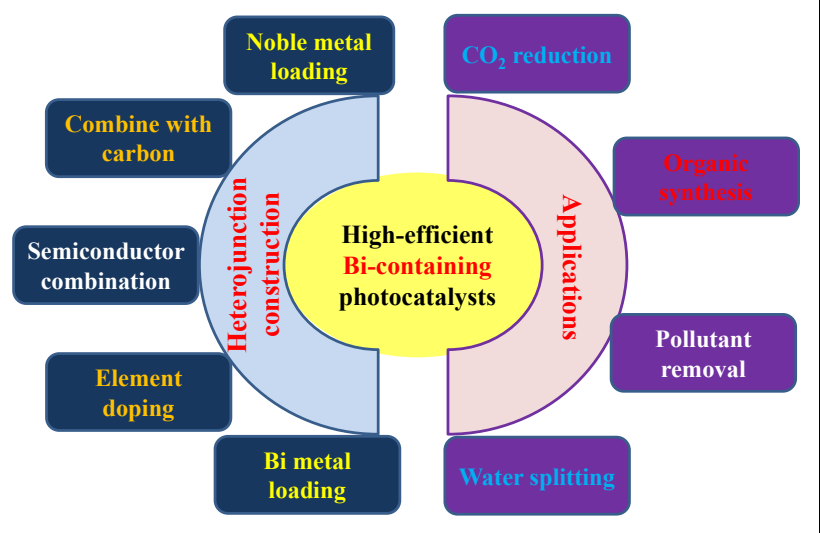


2000, 61, 4850-4861.

[125] A. Hameed, T. Montini, V. Gombac, P. Fornasiero, J. Am. Chem. Soc., 2008, 130, 9658-9659.

[126] H. H. Jiang, J. J. Liu, K. Cheng, W. B. Sun, J. Lin, J. Phys. Chem. C, 2013, 117, 20029-20036.
[127] X. W. Liu, H. Q. Cao, J. F. Yin, Nano Res., 2011, 4, 470-482.

[128] F. Dong, Q. Y. Li, Y. J. Sun, W. K. Ho, ACS Catal., 2014, 4, 4341-4350.

[129] Y. Liu, L. Chen, Q. Yuan, J. He, C. T. Au, S. F. Yin, Chem. Commun., 2016, 52, 1274-1277.

\title{
具有异质结的铋系光催化剂研究进展
}

\author{
陈浪, 贺捷, 刘英, 陈鹏, 区泽堂, 尹双凤* \\ 湖南大学化学化工学院, 湖南长沙 410082
}

\begin{abstract}
摘要: 由于人类面临的能源危机与环境污染问题日益严重, 光催化技术作为最有可能解决这两大问题的技术而备受关注. 其中, 光催化剂是光催化技术的核心. 开发具有宽光谱响应、高载流子分离效率的光催化剂既是研究热点也是难点. 铋系 光催化剂具有较强的可见光吸收能力. 但是, 提高铋系光催化剂对入射光的吸收效率、降低光生载流子复合效率仍是提高 其光催化活性的关键. 目前主要通过以下策略来解决这些问题: (1) 贵金属负载, (2) 半导体复合, (3) 金属/非金属掺杂, (4) 碳材料修饰, (5) 铋金属负载等. 最后还简要探讨了具有异质结的铋系光催化剂的发展趋势及其潜在应用.

采用贵金属负载于铋系光催化剂 (构建肖特基结), 可以通过等离子体共振效应拓宽铋系光催化剂的光吸收范围, 同时 贵金属还能有效转移半导体上的光生电子, 促进光生载流子的有效分离. 但是, 采用贵金属负载存在昂贵、容易发生团聚 等不足. 通过半导体之间构建紧密异质结, 不仅可以调节所制备复合催化剂的能带结构, 满足不同光催化反应的要求, 而 且由于内电场的存在可以促进光生载流子定向转移, 从而提高光生载流子的分离效率. 除此之外, 通过杂原子掺杂可以在 原子层面上构建异质结结构, 也能有效抑制光生载流子的复合. 近年来, 通过与具有较好导电性能的碳材料复合, 可以快 速转移铋系半导体上产生的光子, 提高光催化剂的活性和量子效率. 铋纳米颗粒具有与贵金属类似的性能, 通过采用铋金 属对铋系半导体进行负载也可以发生等离子体共振效应, 从而可以提高铋系半导体的活性. 最后, 作者展望了铋系半导体 复合光催化剂发展的三个重要方向: (1) 创制非化学计量比的铋系半导体复合光催化材料; (2) 通过与还原能力更强的半 导体构建复合光催化材料, 实现光催化 $\mathrm{CO}_{2}$ 还原制备有机物和光催化全解水的应用中去; (3) 充分利用铋系半导体化合物 具有较强氧化能力的优点, 将其应用于光催化有机物合成中, 比如光催化甲苯类有机物选择性氧化等.
\end{abstract}

关键词: 光催化; 铋; 异质结; 可见光

收稿日期: 2016-01-19. 接受日期: 2016-02-20. 出版日期: 2016-06-05.

*通讯联系人. 电话/传真: (0731)88821171; 电子信箱: sf_yin@hnu.edu.cn

基金来源：国家自然科学基金 (21401054, 21476065); 博士后科学基金 (2014M562098); 中央高校基本科研业务费.

本文的英文电子版由Elsevier出版社在ScienceDirect上出版(http://www.sciencedirect.com/science/journal/18722067). 